\title{
ON THE RELATIONSHIP BETWEEN THE GOSPEL AND CULTURE IN SELECTED PUBLICATIONS OF GIUSEPPE MARIA ZANGHÍ
}

This article will deal with Giuseppe Maria Zanghís reflections on the relationship between the Gospel, the Jesus' event, and culture, especially the Western one, since, on the one hand, "the Christian man's culture proposal will arise from the re-establishment of Christ in the center of him or her, and in the center of interpersonal reports. It is a spiritual and moral effort in which one must adapt themselves, society and the world to the «ontological» level to which Christ has already led these realities", on the other hand, "the great crisis of our time, in the West, is the split between the Gospel and culture"2; taking into account the fact that: first, "the Western culture was born

1 G.M. Z a n g h í, Per una cultura, „Nuova Umanità”, 2(1979), p. 17. “The great Christian culture must become capable of showing the enormous transformations brought by Christ (of showing, through his being, that transformation itself), who reconciled everything in himself and led it to the mono-triality." G.M. Z a n g h í, Europa e cultura cristiana, „Nuova Umanità”, 73(1991), p. 12.

2 G.M. Z a n g h í, Per una cultura rinnovata. Alcune piste di riflessione, „Nuova Umanità", 119(1998), p. 503. The Italian philosopher notes that "the two-thousand year way of the Christian culture is the history of continuous penetration by the Gospel into different cultures: Semitic, Greek, Latin, Germanic, Celtic, Slavic. They all were delivered, cleansed and re-organized in the Spirit of Christ, and thus brought to a new expression of their own, just as new was the message brought to those cultures.” G.M. Z a n g h í, Vangelo e cultura. Una breve riflessione, „Nuova Umanità", 49(1987), p. 12. 
from the meeting of the Judeo-Christian Revelation and the genius of the Greek" 3 and that, secondly, the Revelation, the Gospel, not only is the beginning of culture, but also its light, judgment, the horizon in a way unattainable ${ }^{4}$, it can be concluded that there has been the split of "form" and "matter".

Even only a cursory review of the titles of the papers by this Italian philosopher and theologian already demonstrates that the problem of culture is at the center of his research interests; it may suffice to mention only those texts in which the word "culture" (from the Italian word "cultura") is used directly in the titles: Per una cultura; Per una cultura dell'unità; Il sociale come utopia fra politica e fede. Riflettendo sulla crisi della cultura contemporanea; Vangelo e cultura. Una breve riflessione; Europa e cultura cristiana; Prospettive per una cultura cristiana in Europa oggi; Per una cultura rinnovata. Alcune piste di riflessione; Il pensare come amore. Verso un nuovo paradigma culturale. However, other publications may be mentioned as well, which also deal with culture issues such as the following: Per un compimento della laicità europea or Un impegno rinnovato.

In this publication, after a short presentation of Giuseppe M. Zanghís profile ${ }^{5}$, will be presented the most important aspects of his thought, which will be the introduction to the fundamental problem of this article, namely what is the relationship between the Gospel and culture. Such a layout of content is motivated by the fact that neither the figure nor the thought of this contemporary Italian thinker is more widely known to the Polish scholarly community.

Giuseppe Maria Zanghí, a son of Antonio and Caroline from the house of Geniale and a brother of a two-year younger sister Nanda, was born on December 16, 1929 in Syracuse. The family of Zanghídue to Antonio's work - often moved from place to place, so the young

3 G.M. Z a n g h í, Per una cultura rinnovata..., art. cit., p. 508.

4 Cf. G.M. Z a n g hí, Vangelo e cultura..., art. cit., p. 11.

5 Bibliografic note is prepared on the basis of the data collected in P. It a $1 \mathrm{i}$ a, Per una cultura dell'unità. Il pensiero di Giuseppe Maria Zanghí, Rosolini (SR) 2014, pp. 57-59. 
Giuseppe Maria obtained his basic education in different schools, for example, in 1940 the family returned to their native region where G.M. Zanghí graduated from junior high school (from the Italian "la scuola media") ${ }^{6}$ but two years later they moved to Ragusa, remained there until 1949, where Giuseppe ended lycée and then enrolled in the Faculty of Philosophy of the University of Catania. In 1949, Antonio was definitely transferred to Syracuse, while Giuseppe M. Zanghí graduated in the studies with honors, having written a diploma thesis entitled "Il misticismo speculativo di Plotino".

Two years later, in 1951, through friends who were members of the FUCI (la "Federazione Universitaria Cattolica Italiana"), he met one of the first Chiara Lubich's companions, Graziella De Luca, who came to Syracuse to talk about the novel idea of the evangelical life promoted by the still young Focolare Movement. Giuseppe Maria Zanghí, extremely touched by this proposition of life, joined the Movement and completely returned-converted to Christianity. Already in 1954, he joined the Movement in Syracuse, but soon moved to various Italian cities, and in 1956 he finally moved to Rome, where the Center of Movement is based, to contribute to the development of theological studies and research. From there, always for the sake of the Movement, he set off on numerous journeys to not only European countries, and when, in the early 1960s, the first international town of the Focolare Movement was established in Loppiano, where the International Institute for the Religious Studies "Mystici Corporis" was founded, G.M. Zanghí was asked to lead classes in philosophy and theology. Also in this period he began working in the cultural magazine "Ekklesia".

He was ordained in 1973, and six years later he started working for "Nuova Umanità", a scholarly magazine published by Movement

6 "La scuola media" in the Italian educational system cannot be confused with what is known in Poland as a high school (secondary school, technical school or basic vocational school).The Italian "scuola media" would correspond to a junior high school in the current legal status in Poland (April 1, 2017). 
and he was to be its director for more than 20 years and was going to publish most of his papers there (including those mentioned above).

With time passing, the cooperation between Chiara Lubich and Giuseppe Maria Zanghí intensified more and more, so that at her request he took up the organization of the Università Popolare Mariana, whose task would be the theological formation of the "Work of Mary"7 members.

Giuseppe Maria Zanghí died in Rome on January 23, 2015.

The Italian scholar notes not only that the search for the absolute, in which one finds the importance of the lived reality, was and still is the climax of every great culture ${ }^{8}$, but also that "Christianity proclaims to man an Absolut never thought before: One who is Three". One of the consequences of this revelation is the fact that "for the Christian there is no life - and thus there is no world and no thinking and no creating a culture - if not in God within the Trinity"10. G.M. Zanghí stresses that the Western culture has developed around the delight at being ${ }^{11}$, whose understanding has been distorted by the confusion about not-being: the assumption that only being is and not-being is

7 The official name of the Focolare Movement.

8 G.M. Z a n g hí, Dio Padre e teologia, „Nuova Umanità”, 123-124(1999), p. 351. "One is the absolute toward which religious man's search is always called, the search full of passion immersed in asceticism, which is required by this One." G.M. Z a n g h í, Verso l'Uno che è Amore, „Nuova Umanità”, 87(1993), p. 3.

9 G.M. Z a n g h í, Notte della cultura europea. Agonia della terra del tramonto?, Città Nuova, Rome 2007, p. 54. "One is (...) that Whom the Christian message reveals to man, contemplating what thought and religion have dared to say, but transforming Him radically into the radical novelty of One revealed by Christ." G.M. Z a n g hí, Verso l'Uno..., art. cit., p. 3.

10 G.M. Z a n g h í, Per una cultura, art. cit., p. 17.

1 G.M. Z a n g h í, Un impegno rinnovato, „Nuova Umanità”, 101(1995), p. 5. "Among the Greeks, who initiated the western reflection, the thought inhabited by a mysterium adopted a particular aspect which we call philosophy: instead of immersing itself in the absolute, to move inward, the Greek thought sets itself opposite the absolute and asks for it." G.M. Z a $\mathrm{ng}$ h í, La filosofia ha oggi ancora un destino?, „Nuova Umanità”, 108(1996), p. 623. 
not $^{12}$ - equivalent to the arbitrary exclusion of not-being from Being meant reducing the Being to a certain concept or being non-personal at all. However, the receiving of the mission by Jesus of Nazareth should imply a change in thinking because this Jesus Christ teaches us that God (Being, Absolute) is uni-trinity ${ }^{13}$ - starting from his words, one can discover that in Being there is Three and that each of Them is not Second/Another ${ }^{14}$ : that is why the acceptance of the Gospel, i.e. following Jesus Christ, means believing in God-Trinity, allows man to discover that the identity in this God-Trinity is not a negation of multiplicity (after all, He is a Trinity), but rather the maximum intensity of unity ("Believe in one God") communicated by the Word ${ }^{15}$, the same Word who placed the God who is Love in the center of the Word's spreading the Gospel - from the kenosis of the Incarnation (cf. Phil 2: 7) to being abandoned on the cross (see Mat 27: 46 par. $)^{16}$. The (de)construction of ontology should therefore start from the analysis of the event of Jesus Christ because "He is a knot, ontological and existential, which unites the Absolute and the

12 Cf. E. B e r t i, E s s e r e, in: M. Fe r r a r i s (ed.), Storia dell'ontologia, Bompiani, Milan 2009, pp. 32-33.

13 Cf. B. M a g g i o n i, La Trinità nel Nuovo Testamento, „La Scuola Cattolica”, 118(1990), pp. 7-30.

14 Cf. G.M. Z a n g hí, Verso l'Uno..., art. cit., p. 10. This fact was dogmatized by the Council of Florence in the Bull Cantate Domino, which states that ,hae tres personae sunt unus Deus, et non tres dii: quia trium est una substantia, una essentia, una natura, una divinitas, una immensitas una aeternitas, omniaque sunt unum, ubi non obviat relationis oppositio". DH 1330. (It is good to emphasize, however, that this fundamental principle for trinitology was first formulated by Anzelm of Canterbury in his De processione Spiritus Sancti). As a consequence, it must be recognized that the acceptance of faith in the Triune God cannot cause the negation of multiplicity (in culture), since it is "an absolute which is one and is not also a Trinity - and we have the evidence of that fact in the oriental reflection - leads to the negation of multiplicity" and not vice versa. G.M. Z a n g h í, Per una cultura, art. cit., p. 15 .

15 Cf. Ibid., p. 15.

16 Cf. G.M. Z a n g h í, Prospettive per una cultura cristiana in Europa oggi, „Nuova Umanità”, 73(1991), p. 91. 
creation. The real humanity of Jesus - from the Bethlehem cave to the cross - is a confirmation of the metaphysical and physical stability of the created world. The fact that Jesus is the Word of God is the evidence of an intimate presence of the Absolute in His creatures, different from Him - thus true in themselves - but united with Him in a relationship of love in its climax, which is the Incarnation" ${ }^{\prime 17}$.The Christian revelation results in consideration that in the ontological reflection there is "a place for being - which is a gift, for being - which is an act of communion (...), there is a place for being as a presence which is endlessly giving itself: love"18. Italian thinker complains, however, that the revelation in which it is expressed what the Being is, remains almost absent from the thinking, and thus practically not worked out in the speculation ${ }^{19}$.

The philosophical reflection confirms that God cannot be if not just one, so that if the same thought believes in God who is love (cf. 1 John 4: 8), it cannot fail to accept that God must be one as there is only one love striving toward the loved one: like love divided into two, would not be true love, in the same way two absolutes would not be any absolute ${ }^{20}$. Having departed from this idea, one can conclude that "philosophy must derive from the mystery of Being, from this Being-who-is-Love, who is manifested precisely in non-being of the Cross, if it is understood as expressing the profound reality of being: this not-being in which being determines itself, is in the act"21. On the other hand, it should also be pointed out that, like philosophy should

17 G.M. Z a n g hí, Per una cultura rinnovata..., art. cit., p. 509.

18 G.M. Z a n g h í, Considerazioni su un'ontologia dell'unità e della distinzione, „Nuova Umanità”, 79(1992), p. 13.

19 G.M. Z a n g h í, La filosofia ha..., art. cit., p. 629. Cf. also G.M. Z a n g h í, Vangelo e cultura..., art. cit., p. 13; Un impegno rinnovato, art. cit., p. 7.

20 Cf. G.M. Z a n g hí, Il mistero di Dio Uno, „Nuova Umanità”, 108(1996), p. 662 .

${ }^{21}$ G.M. Z a n g h í, La filosofia ha..., art. cit., p. 637. In another place he writes that "there has always been a certain ontology, but an ontology of unity and distinction appeared - was shown - with Christ and we are trying to update it in the realization of man in Christ." G.M. Z a n g h í, Considerazioni su..., art. cit., p. 14. 
rethink the idea of Being (because it does not reflect over Being-Love $)^{22}$, so theology has to ask itself whether and how much it was penetrated by the mystery of God's uni-trinity ${ }^{23}$. In other words, both the philosophy and the theology must refer to the Incarnation and the cross of $\mathrm{Christ}^{24}$, and answer the question: what does this mean for one and the other discipline and, above all, man?

On the cross reveals itself the dynamism of love - which is expressed by giving itself" 25 love, which is God, who in Christ "reveals himself as a complete donating, not lacking, which is looking for filling, but plenitude, which strips itself for love. And that us why it is"26.

22 G.M. Zanghí notes that, having reached the heights of speculation in the context of Trinitarian theology "with the next step one never descended to the created being, in order to achieve this vision of beings and man, which even today assumes Trinitarian revelation", so "the authentic and renewed philosophy -continues the Italian thinker - must discover apart from the conceptual contribution - an important one, but always provisional- the deepest moment, the one in which the thought gives himself to the Absolute and allows Him (...) to express himself in human thought." G.M. Z a n g h í, La filosofia ha..., art. cit., pp. 628.635.

23 Cf. G.M. Z a n g h í, Notte della cultura europea..., op. cit., pp. 55.59.

24 Cf. Ibid., p. 60. "The difficult and violent event of abandonment must have confused successive generations of Christians, called to rethink, in the light of the mystery of the cross, the idea of God inherited from previous cultures (...). However, this reality of abandonment in its ontological depth remained immeasurable. Only some great mystics were not afraid to get closer their great trials to Jesus' abandonment, in order to find in it the sense of what they were experiencing." G.M. Z a n g h í, Spunti per una teologia di Gesù Abbandonato, „Nuova Umanità”, 102(1995), p. 13.

25 Cf. G.M. Z a n g h í, Considerazioni su..., art. cit., p. 13.

26 G.M. Z a n g h í, La filosofia ha..., art. cit., p. 634. It should be emphasized that the using of «usia» makes it difficult to try to explain the kenosis, not only because this classic category per se excludes humility, emptying or other activities established within the framework of the Trinitarian kenosis (excludes the change), but also because its using makes it impossible to describe the dimension of self-donation, which G.M. Zanghí and others write about. Cf. T. L o n g h i t a n o, Vita trinitaria kenosi, Urbaniana University Press, Vatican 2013, p. 28. G.M. Zanghí himself puts it in this way: "If Absolute gives himself as Trinity it must be understood as such. And can it happen without curing philosophical categories and without extending and supplementing them?" G.M. Z a n g h í, Vangelo e cultura..., art. cit., p. 13. 
G.M. Zanghí clearly shows love ${ }^{27}$, a relationship of reaching out for the other in an intimate communion ${ }^{28}$, as a conceptual scheme most suitable for the expression of a new ontology. This love is expressed by Jesus Christ in a special way through his death and resurrection ${ }^{29}$ because it is "in the abandonment on the cross, lived as love, what is made void is «negative» non-being and what is revealed, in the heart of Being, is «positive» not-being (relations) as the secret of that Being through which the Being is love" 30 .

This brief introduction to Giuseppe Maria Zanghi's thought allows us to state that for him the key to Jesus' event is the Passion, Death and Resurrection, and that is where the point of departure for further reflection - relating to culture -should be sought.

G.M. Zanghí in his initial reflections does not want to define directly what culture is, he rather prefers to say when one has that culture, and one has it when "the multitude of human expressions are brought to unity" 31 , in other words, one has a culture when the multiplicity expressing itself hic et nunc is gathered into unity and directed to exceeding oneself. In this sense, the unity which organizes

27 It should be noted that G.M. Zanghí, as K. Hemmerle or G. Greshake, in attempting to construct the so-called Trinitarian ontology does not refer primarily to the classical terms (such as «usía», «hypóstasis», «phýsis», «prósōpon»), but seeks to present intra-trinitarian life as a dynamic reality of giving oneself and hence he is primarily concerned with the analysis of the notion of love." Cf. I. S a n na, L'antropologia cristiana tra modernità e postmodernità, Queriniana, Brescia 2001, p. 442 .

28 Cf. G.M. Z a n g h í, Verso l'Uno..., art. cit., p. 6. Cf. also K. H e m m e r le, Tesi di ontologia trinitaria. Per un rinnovamento del pensiero cristiano, Città Nuova, Rome 1996, p. 49.

29 G.M. Z a n g hí, Considerazioni su..., art. cit., p. 25.

30 G.M. Z a n g h í, Verso l'Uno..., art. cit., p. 12. "The great ontological discourse started by the Greeks, adopted by the Fathers and scholastics Masters, (...), should be re-examined in the Trinitarian key today, in which its place has a no-being. Not no-being as something external which negates this being, (...); but no-being as a herald of depth, I would say the heart of Being which is Love.” G.M. Z a $\mathrm{n} g \mathrm{~h}$ í, La filosofia ha..., art. cit., p. 363.

31 G.M. Zanghí, Per una cultura, art. cit., p. 4. 
this multiplicity in culture, on the one hand, is an achieved effort and the point of arrival of the exploration within the multiplicity, on the other hand - it is what directs, overtakes and manages that exploration ${ }^{32}$.

He provides a definition of culture in another, later article of his: "culture is a summary (from the Italian word "condensato") - «here and now», always open to changes-of answers, structures, projects that are born from the interior of every man posted in front of the world, the people, God (Absolute)"33. In this context, it becomes clear what the multiplicity is and that is is to be brought to unity: questions, answers, structures and projects that are set, given, created, invented, when one recognizes itself as different from the world, the other and God (as another, i.e. non-world, non-second-person and non-God).

At this point what should be made is a reference to the concept of the Gospel which the Italian thinker understands as "the final act by which the Father in the Son and in the Spirit enters into the heart, into the human's interior, from where it spreads (...) in all its spheres, until everything will be one in the communion of the Trinity" ${ }^{4}$. So, the Gospel is not a culture, but it is certainly culture-creating, because "the heart of man, reached by the Gospel and inhabited by Trinity, has to create a «christian» culture, which expresses the «novelty» of a man-in-Christ" 35 , and that because "in him we live, we move and we have our being" (Acts 17: 28).

A man who creates a Christian culture is to bring everything to unity, just as One is the Father with the Son in the Holy Spirit. The Gospel must undoubtedly influence the way of thinking of multiplicity because it does not proclaim an absolute closed within itself and to itself in some monolithicity lost to any communion, on the contrary, the Christian Absolute is open in itself because It manifests itself in multiplicity; therefore since the events of Christ

\footnotetext{
32 Cf. Ibid., p. 4.

33 G.M. Z a n g h í, Vangelo e cultura..., art. cit., p. 11.

34 Ibid., p. 11.

35 Ibid., p. 11.
} 
one has not proclaimed: an absolute is, but the Absolut we are (cf. John 10: 30) ${ }^{36}$ - eo ipso the Gospel should affect the concept of the unity and the relationship between this unity and multiplicity. From this it follows that a particular "Christian culture (...) cannot fail to articulate itself in a rich set of forms; (...) because the Absolute, who resides and is now manifested in the human heart is the Trinity, and therefore that the Father loves in the only Son each of his sons with love completely personal" ${ }^{37}$ - Christian culture has guaranteed the unity in the person of the Son and multiplicity in the persons of sons. What directs the multitude to unity, is ahead of the multitude, and who governs it, is Jesus Christ.

The event of Jesus begins with his Incarnation in which "God himself has taken a human physicality and spirituality, and through them has included creation into himself, integrating with it" 38 , i.e. led some multiplicity to the unity. At this point one can be tempted to say that an ontological structure of man already calls him to unite creation within himself. This vocation has been perfectly fulfilled by the Son of God, who accepted - and made his - a difference, united with it. What is important is that adopted humanity of the Word has not only a soteriological function ${ }^{39}$, but also an informative one, because in fact it reveals the mystery of being at the height point of the crucifixion, which is for G.M. Zanghí the experience of abandonment ${ }^{40}$. This moment, the moment of Golgotha "is the beginning of the way of the Christian culture, always rising from the abyss of abandonment (...) into the light of Easter morning" "41. Therefore, Giuseppe Maria Zanghí is not afraid to say that "on the one hand, the Christian culture has to be a witness of the resurrection - in which great human problems

36 Cf. G.M. Z a n g h í, Prospettive per una cultura..., art. cit., p. 84.

37 G.M. Z a n g h í, Vangelo e cultura..., art. cit., p. 11.

38 Ibid., p. 13.

39 'In Christ's humanity each created person is brought to life without end, where the history and the search are saved and completed, but that does not mean that they are being lost." Ibid, p. 14.

40 Cf. G.M. Z a n g hí, Un impegno rinnovato, art. cit., p. 7.

${ }^{41}$ G.M. Z a n g h í, Prospettive per una cultura..., art. cit., p. 176. 
are called to transcend themselves, to be reassembled in uni-trinity and open to a new life within this one-trinity; on the other hand, the Christian culture is also the memory and testimony of kenosis and the abandonment of the Lord on the cross. And these two moments abandonment and resurrection - should not be disconnected, even if they are separate (from the Italian word "distini")" "'. It is precisely at the moment of abandonment, when Jesus Christ calls, "My God, why have you forsaken me?" (Mk 15: 34), that the Holy Spirit is given to the human race (John 7: 39; 19: 3): Christian culture is called to rediscover this event, as the Spirit lives in the world and makes it Christ $^{43}$ - brings some multiplicity to the unity.

Another task of the Christian culture, i.e. flowing from the Gospelthe event of Christ - is to show in all beings, and above all in the relations between these entities, the reality of the Trinity ${ }^{44}$, is to set in all a relationship, of any type - whether it is practical or cognitive which will be involved in the one that builds all the others, which Christ and the Father are to one another in the Spirit ${ }^{45}$; that is why the Italian theologian rightly observes: "The Christian culture (...) is capable per se, out of vocation, of the adoption of diversity (from the Italian word "il diverso") as its category. It does not set itself up as a culture next to another, or as anti-culture, but as a space in which every culture, living man, opens up historically to its completed (from the Italian word "compiuto") expression" "any expression of Christian, if it is truly such, cannot be definitive. On the one hand, because man is a temporal being, so it is defined in a certain historical process; on the other, because Christianity slowly penetrates the depths of a man: first of all, because it is love, and

42 G.M. Z a n g hí, Europa e..., art. cit., p. 12.

43 Cf. G.M. Z a n g h í, Prospettive per una cultura..., art. cit., p. 94.

44 Cf. G.M. Z a n g h í, Per una cultura rinnovata..., art. cit., p. 510.

45 Cf. G.M. Z a n g h í, Per una cultura dell'unità, „Nuova Umanità”, 10-11(1980), p. 25 .

46 G.M. Z a n g h í, Per un compimento della laicità europea, „Nuova Umanità”, 73(1991), p. 176. 
love does not commit violence" ${ }^{" 47}$. Christian culture, or a living man: for G.M. Zanghí, it is obvious that "if we think of man as a person, we cannot exclude anything from what expresses him, if we want to have a certain integral culture (from the Italian word "integrale")", so "for a «Christian» culture it is necessary to bring work as man's true vocation." $"$.

This article presents the silhouette of the contemporary Italian Catholic thinker, Giuseppe Maria Zanghí (1929-2015), and the most important aspects of his philosophical and theological system, which provided the basis for his theory of culture. A theory that can definitely be called Trinitarian, and that is the case because it comes from the analysis of the ontological situation that follows the Revelation brought to us by Jesus Christ. This revelation should change - and in the opinion of the Italian thinker - has somewhat changed - the way of perceiving Being, i.e. God, and hence the relationships that connect man to other people (more widely, to the society) as well as the world, and God himself. Considering the wealth of content, it was decided to choose the themes in the thought of the Italian scholar which are most characteristic of him, realizing that his research into his philosophy and theology should be continued.

Man, the creator of culture, contemplating the Word of God Jesus Christ - must convey the relationships that connect the Person in the Trinity onto the whole surrounding reality, which has always been Trinitarian, but which should have become obvious since the moment of abandonment of the Son of God on the cross when the Spirit Renewer was given to us.

47 G.M. Z a n g hí, Europa e..., art. cit., pp. 10-11.

48 G.M. Z a n g hí, Per una cultura, art. cit., p. 19. 


\section{O relacji między Ewangelią a kulturą w wybranych publikacjach Giuseppe Marii Zanghiego Streszczenie}

W artykule poruszono zagadnienie rozumienia kultury w świetle tak zwanej ontologii trynitarnej. Taką refleksję proponuje Giuseppe Maria Zanghí, współczesny - zmarły przeszło dwa lata temu - włoski filozof i teolog, związany z Chiarą Lubich oraz ufundowanym przez nią Ruchem Focolare. Elementami kluczowymi są analiza wydarzenia Chrystusa - od Inkarnacji aż do opuszczenia na krzyżu, jak również następującego po nim Zmartwychwstania. W artykule omawia się krytykę ontologii dokonaną przez G.M. Zanghiego, jego propozycję rekonstrukcji tej gałęzi nauki oraz możliwe jej konsekwencje dla kultury zachodniej.

\section{Summary}

The article addresses the issue of understanding of culture in the light of the so-called Trinitarian ontology. Giuseppe Maria Zanghí, a contemporary, who died two years ago, is an Italian philosopher and theologian associated with Chiara Lubich and the Focolare Movement founded by her. The key elements are the analysis of the events of Christ - from the Incarnation to the Cross, as well as the Resurrection after it. This article discusses the criticism of ontology by G.M. Zanghí, his proposal to recreate this branch of science and its possible consequences for the Western culture.

Słowa kluczowe: Giuseppe Maria Zanghí, ontologia trynitarna, kultura, wydarzenie Chrystusa

Keywords: Giuseppe Maria Zanghí, Trinitarian ontology, culture, Christ's event

Nota o autorze: Szymon Krzysztof Ciećko (ur. 1988), doktorant na Wydziale Teologicznym UKSW w Warszawie. Zainteresowania badawcze koncentrują się na zagadnieniach dogmatycznych, w tym tak zwanej ontologii trynitarnej.

\section{Bibliography:}

Berti E., Essere, in: Ferraris M. (ed.), Storia dell'ontologia, Bompiani, Milan 2009. Hemmerle K., Tesi di ontologia trinitaria. Per un rinnovamento del pensiero cristiano, Città Nuova, Rome 1996.

Italia P., Per una cultura dell'unità. Il pensiero di Giuseppe Maria Zanghì, Rosolini (SR) 2014. 
LonghitanoT., Vita trinitaria kenosi, Urbaniana University Press, Vatican 2013.

Maggioni B., La Trinità nel Nuovo Testamento, „La Scuola Cattolica” 118(1990), pp. 7-30.

Sanna I., L'antropologia cristiana tra modernità e postmodernità, Queriniana, Brescia 2001.

Zanghí G.M., Considerazioni su un'ontologia dell'unità e della distinzione, „Nuova Umanità" 79(1992), pp. 11-26.

Zanghí G.M., Dio Padre e teologia, „Nuova Umanità” 123-124(1999), pp. 351-355.

Zanghí G.M., Europa e cultura cristiana, „Nuova Umanità” 73(1991), pp. 3-17.

Zanghí G.M., Il mistero di Dio Uno, „Nuova Umanità” 108(1996), pp. 661-667.

Zanghí G.M., La filosofia ha oggi ancora un destino?, „Nuova Umanità” 108(1996), pp. 621-638.

Zanghí G.M., Notte della cultura europea. Agonia della terra del tramonto?, Città Nuova, Rome 2007.

Zanghí G.M., Per un compimento della laicità europea, „Nuova Umanità” 73(1991), pp. 175-178.

Zanghí G.M., Per una cultura dell'unità, „Nuova Umanità” 10-11(1980), pp. 8-28.

Zanghí G.M., Per una cultura rinnovata. Alcune piste di riflessione, „Nuova Umanità" 119(1998), pp. 503-519.

Zanghí G.M., Per una cultura, „Nuova Umanità” 2(1979), pp. 1-20.

Zanghí G.M., Prospettive per una cultura cristiana in Europa oggi, „Nuova Umanità” 73(1991), pp. 81-94.

Zanghí G.M., Spunti per una teologia di Gesù Abbandonato, „Nuova Umanità” 102(1995), pp. 9-31.

Zanghí G.M., Un impegno rinnovato, „Nuova Umanità” 101(1995), pp. 3-7.

Zanghí G.M., Vangelo e cultura. Una breve riflessione, „Nuova Umanità” 49(1987), pp. 7-18.

Zanghí G.M., Verso l’Uno che è Amore, „Nuova Umanità” 87(1993), pp. 3-13. 